\title{
Utilization of Blockchain Technology Revolution in Electronic ID Card Data Integrity
}

\author{
Irvan Arif Kurniawan', Dede Yusman², Indri Okshana Aprilia ${ }^{3}$ \\ Faculty of social and political sciences \\ ${ }^{123}$ Universitas Islam Syekh Yusuf, Indonesia \\ Email: iakurniawan@unis.ac.id ${ }^{1}$, dedeyusman98@gmail.com², iinokshana@gmail.com³
}

\section{To cite this document :}

Kurniawan, I., Yusman, D., \& Aprilia, I. (2021). Utilization of Blockchain Technology

Revolution in Electronic ID Card Data Integrity. Aptisi Transactions on Management (ATM), 5(2), 137-142.

DOI :

https://doi.org/10.33050/atm.v5i2.1530

\begin{abstract}
KTP is a proof of identification issued by the implementing agency that applies throughout the territory of the Unitary State of the Republic of Indonesia. The existence of KTP is recognized as very important in daily life because it is used in all activities or any series of administrative transactions. Field studies found the number of cases of Asphalt ID cards (original but fake) used as a means of media fraud. Because ID cards are very easy to falsify this makes it difficult to identify cases of data misappropriation. The focus of the research was the utilization of Blockchain, by applying distributed consensus and cryptography in improving the administration management system of KTP to identify the existence of fake IDs and double data. The research method used is descriptive analysis method and literature study. By implementing the decentralization and cryptographic system owned by Blockchain, it is expected to minimize the occurrence of identity misappropriation, as well as be able to be a technology capable of contributing to the success of aspects of state administration governance systems.
\end{abstract}

Keywords: KTP, Administration, Blockchain, Data Misappropriation.

\section{Introduction}

Regulated in the Act. No.23 of 2006 and Presidential Regulation No.35 of 2010 which discusses the regulations and changes in the application of the national ID card administration system based on the Parent Number [1]. Government policy in the Act is to enforce the E-KTP system created to create a consensus of a nationally centralized database, with the enactment of biometric systems. which means, that each owner of e-KTP will be connected into a series of centralized database units that will be interconnected nationally so that, everyone only has one KTP only [2]. With the making of the e-KTP administration system, it is intended to create an orderly administration. In addition, the regulation is used to prevent and avoid the existence of double data and misuse of ID cards that will impact and cause harm to the state.

Industrial Revolution 4.0 contributed a lot of great influence and the impact felt was very significant. With this increasingly recent industrial revolution. So all kinds of human activities will be closely related to technology, even all information dissemination activities are closely related to technology [3]. Technology also brings an inferior impact, one of which is the activities of misappropriation of KTP data carried out for fraudulent activities carried out by an irresponsible person. Although the enactment of the Law governing the administration of ID cards issuance but still many cases of fake ID cards found in the community, this will obviously cause unrest and many losses caused by the problem [4]. The question is whether the system current administrative governance has been able to coordinate the matter. The principle of e-government used to improve the quality of administrative governance services is also in line with the principles owned by blockchain, where blockchain has uniqueness including transparency, immutable and distributed. Blockchain itself is a digital recording and storage system connected to a series of chains connected through cryptography. Blockchain was first introduced in the banking sector or 
commonly known as Bitcoin, but nowadays blockchain has been widely applied in many sectors, one of which is administrative management [5].

\section{Problems Analysis}

The case of KTP misuse has now become more widespread, even the motives of the misuse of ID cards themselves have become more diverse, but clearly the only thing done is to commit criminal acts or fraud. Fraudsters began to dare to do their activities and even used to apply for money as bank customers. Of course this will contribute a lot of losses and soon found a solution [6]. Based on these problems blockchain technology revolution will be able to eliminate the occurrence of ID card misappropriation and the occurrence of double data. By utilizing the decentralization and cryptographic system owned by blockchain, it will be able to be minimized. The uniqueness of blockchain is immutable which means it cannot be changed or permanent. Data added to the Blockchain consensus will be encrypted through a unique code called a hash. This results in data that has been inputted will not be possible to be changed or deleted, because the principle of the individual immutable is, can only create without being able to perform data deletion activities, because each transaction that occurs has a different hash code [7].
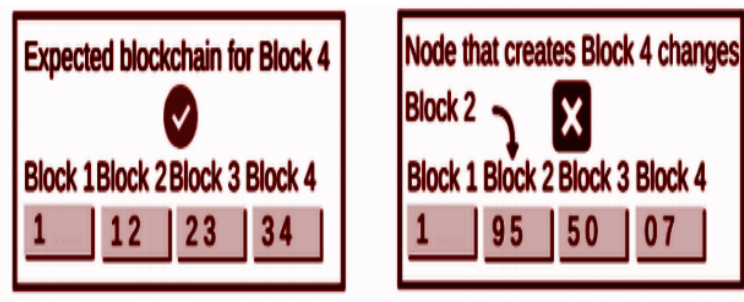

Figure 1.Blockchain hashed code.

A simple hash concept in cryptography is a mathematical algorithm that maps data randomly in the form of strings or hashes.

\section{Research Methods}

The research method is aimed at obtaining reliable and accurate information. The research method used is a scientific method that is simply able to decipher the theoretical understanding of science [8]. And descriptive analysis methods are used to weigh and measure the characteristics of a tested data. in addition, the study of literature studies is used to be able to find references from such research so that it can be used as a benchmark in conducting research and obtaining information from various studies [9].

\section{Literature Studies}

In this study, the authors adopted 5 (five) literature studies that were used as a reference in the research. Research in 2019 with the title "Design E-transcript With Blockchain Technology" this research discusses blockchain technology used in the management of Diploma Transcript publishing systems [10]. In addition, the research titled "Blockchain Implementation: E-Voting Case Study" is a study conducted in 2019 by Satria Damai Kurnia Hu's brother, Dkk [11].

Which in his research raised the subject of blockchain is able to facilitate the implementation of voting aimed at avoiding the occurrence of double data so as to minimize the occurrence of fraud. In 2019, research conducted by Susanto, Dkk under the title "Smart Contract Blockchain on E-Voting" Blockchain was used to run the e-voting process with several process flows consisting of voter identity with KTP and blockchain address in each TPS [11]. "Implementation of KTP e Program in the Framework of Orderly Population Administration" is a research title that has been conducted in 2017 [12].

where in this study raised topics related to KTP as an official document of residence equipped with a security system and administration based on the national population database. Febriarini in 2017 has conducted research with the title "Implementation of e KTP Program in the Framework of Orderly Population Administration" in his research explaining the purpose of the enactment of E-KTP is to realize administrative order on a national scale [13]. 
Of the five library studies that have been described are able to describe some similar research that has been done before, especially on research that focuses on the system of managing the administration of KTP [14].

\section{Results And Discussions}

In 2020 alone, the total population of Indonesia reached 273,523,615 million people who were divided into several groups consisting of age and gender. The data was obtained based on the results of a population census survey. The number of people in the country from 2015 to 2020 is projected to reach 266.91 million people. That consists of the number of male sexes of 134 million and the data with the female sex of 132.89 million people [15].

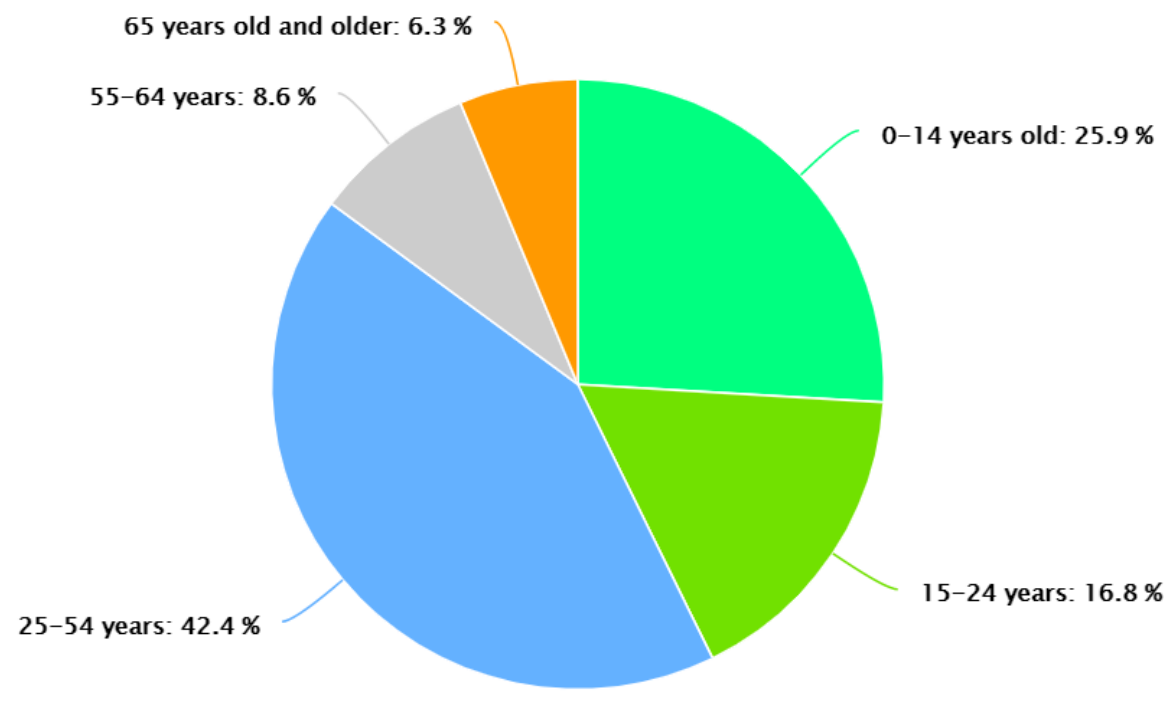

Figure 2. Population chart 2020

In 2020 it is projected that Indonesia's population will be $273,523,615$ people, while in 2019 it will be $270,625,568$. This means an increase of $3,028,072$ people or 1.15 percent (\%). In 2020 , the average age of Indonesia's population is 29.7 years with a population fertility rate of 2.32. Judging from the age group, the population aged $25-54$ years is more than other age groups, namely $42.4 \%$. Meanwhile, the population aged 0-14 years reaches 25 percent of the total population in 2020 .

\begin{tabular}{|c|c|c|c|c|c|c|c|c|c|c|c|}
\hline Year & Population & $\begin{array}{c}\text { Yearly } \\
\% \\
\text { Change }\end{array}$ & $\begin{array}{l}\text { Yearly } \\
\text { Change }\end{array}$ & $\begin{array}{l}\text { Migrants } \\
\text { (net) }\end{array}$ & $\begin{array}{l}\text { Median } \\
\text { Age }\end{array}$ & $\begin{array}{l}\text { Fertility } \\
\text { Rate }\end{array}$ & 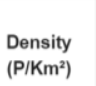 & $\begin{array}{c}\text { Urban } \\
\text { Pop } \\
\%\end{array}$ & $\begin{array}{c}\text { Urban } \\
\text { Population }\end{array}$ & $\begin{array}{l}\text { Country's } \\
\text { Share of } \\
\text { World Pop }\end{array}$ & $\begin{array}{c}\text { World } \\
\text { Population }\end{array}$ \\
\hline 2020 & $273,523,615$ & $1.15 \%$ & $3,028,072$ & $-98,955$ & 29.7 & 2.32 & 151 & $\begin{array}{r}56.4 \\
\%\end{array}$ & $154,188,546$ & $3.51 \%$ & $7,794,798,739$ \\
\hline 2025 & $287,089,635$ & $0.97 \%$ & $2,713,204$ & $-105,450$ & 31.0 & 2.32 & 158 & $\begin{array}{r}59.3 \\
\%\end{array}$ & $170,361,295$ & $3.51 \%$ & $8,184,437,460$ \\
\hline 2030 & $299,198,430$ & $0.83 \%$ & $2,421,759$ & $-100,007$ & 32.4 & 2.32 & 165 & $\begin{array}{r}62.1 \\
\%\end{array}$ & $185,755,185$ & $3.50 \%$ & $8,548,487,400$ \\
\hline 2035 & $309,764,944$ & $0.70 \%$ & $2,113,303$ & $-94,464$ & 33.8 & 2.32 & 171 & $\begin{array}{r}64.6 \\
\%\end{array}$ & $200,062,259$ & $3.49 \%$ & $8,887,524,213$ \\
\hline 2040 & $318,637,858$ & $0.57 \%$ & $1,774,583$ & $-94,465$ & 35.1 & 2.32 & 176 & $\begin{array}{r}66.8 \\
\%\end{array}$ & $212,896,712$ & $3.46 \%$ & $9,198,847,240$ \\
\hline 2045 & $325,705,348$ & $0.44 \%$ & $1,413,498$ & $-94,247$ & 36.2 & 2.32 & 180 & $\begin{array}{r}68.8 \\
\%\end{array}$ & $224,183,450$ & $3.44 \%$ & $9,481,803,274$ \\
\hline 2050 & $330,904,664$ & $0.32 \%$ & $1,039,863$ & & 37.4 & 2.32 & 183 & $\begin{array}{r}70.7 \\
\%\end{array}$ & $234,104,967$ & $3.40 \%$ & $9,735,033,990$ \\
\hline
\end{tabular}

Table.1 Indonesia Population 
The number of world population in 2020 is estimated at 7,794,798,739 people. With a population of $273,523,615$ people, Indonesia ranks fourth in the world's most populous country. In terms of gender, the total male population of Indonesia is $137,717,861$ people or 50.35 percent. While the female population is $135,805,760$ people or 49.65 percent.

With the large number of population data that always increases every year, of course crime continues to increase, especially in the misuse of fake ID cards [16]. The Directorate General of Population and Civil Registration (Ditjen Dukcapil) deleted various pages and images relating to the misuse of population data, especially KTP and KK circulating on the internet.

In addition to a number of complaints about not being able to register, the appearance of a website containing a free National Identification Number (NIK) and Family Card (KK) has also troubled the public. In circulation, a number of sites are claimed to contain NIK and KK which can be used for prepaid SIM card registration. As is known, customers must include their NIK and KK to be able to register a SIM card. Therefore this research was conducted to be able to reduce the number of KTP abuse by embedding blockchain revolutionary technology with its characteristics, namely decentralization and trustles [17].

\begin{tabular}{|c|c|c|}
\hline \hline Generation & Application Type & Application Examples \\
\hline 1.0 & Financial Transactions & Bitcoin \\
\hline 2.0 & Smart Contracts & Ethereum \\
\hline 3.0 & Government, Science & EOS \\
\hline 4.0 & Developing & Seele \\
\hline \hline
\end{tabular}

Table 2. blockchain generation cycle.

Measured at the macro level described in table. 1 blockchain technology and its application seen from aspects of its development globally it can be concluded that blockchain can be used as one of the aspirations in the effort to become an increasingly advanced and open world. This factor brings it to the macro level which will then be able to support cultural values and include aspects of transparency that will make an anti-government repression system. When viewed in terms of data infrastructure presented by blockchain [18]. it will be concluded that a comprehensive governance system will guarantee the process of structuring the governance system of the data management system, especially in cybersecurity and information [19].

In the efforts to manage infrastructure and regulations and efforts to be taken in an effort to answer existing expectations, the path that must be taken and taken is the Government is required to make breakthroughs in the steps to improve the system and governance of KTP data integrity in Indonesia. In this research conducted by adopting blockchain will be able to reduce the amount of double data and asphalt data with immutability and distributed ledger system owned by blockchain which is a key characteristic owned [20].

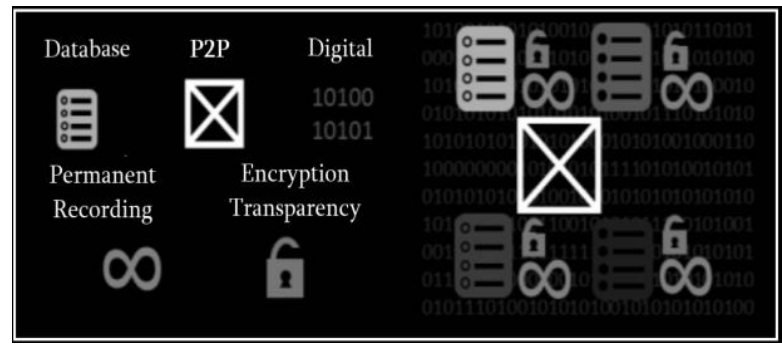

Figure 3. Illustration of ktp working system with blockchain technology 
Figure 3. is an illustration or illustration of a working system running within an E-KTP with blockchain technology. Where, blockchain has 5 (five) main concepts, among others, blockchain works peer-to-peer, KTP database system will be distributed decentralize, digital data system will be stored permanently, and data transparency will be done by encryption by cryptographic method. This, of course, will provide a governance system that will provide improvements in terms of data security [21].

E-KTP systems with blockchain technology can be applied as an effort in the step of updating the E-KTP issuance system infrastructure carried out by the civil registration population office or DISDUKCAPIL. The application of cryptographic systems, by encrypting every KTP issued by DISDUKCAPIL is an effort or step in improving data integrity, so that the data will not be manipulated, so that asphalt data can be suppressed [22].

As for the positive impact of the implementation of blockchain systems in E-KTP, in terms of security blockchain technology is very up-to-date and very effective. In addition, the application of digital signatures can be done confirming the identity of the person applying the blockchain system [23]. And from these signatures can also set data permissions and provide a trace of access history of the identity data [24].

\section{Conclusion}

In the era of industry 4.0 life is inseparable from the existence of digital technology. The presence of blockchain is very beneficial for data and identity security. The current application of blockchain is not only applied in the Financial field but, various industrial sectors have also implemented the blockchain technology revolution in an effort to ensure data integrity that can be trusted and accountable for its authenticity.

For example, the agricultural sector today has even implemented blockchain in data integrity. This does not close the possibility that the government can adopt blockchain systems in an effort to protect state files such as ID cards in order to ensure a good management of data integrity. With good data integrity, the government is able to eliminate the occurrence of data misappropriation carried out in criminal acts.

This research was conducted in an effort to improve the E-KTP system with blockchain technology in improving data integrity in the Disdukcapil system. Suggestions for further research, in an effort to improve the data integrity system of KTP can be applied and developed to be able to build an infrastructure of KTP issuance management.

\section{Reference}

[1] F. M. Yunus and Z. Aini, "Perkawinan Beda Agama Dalam Undang-Undang Nomor 23 Tahun 2006 Tentang Administrasi Kependudukan (Tinjauan Hukum Islam)," Media Syari'ah Wahana Kaji. Huk. Islam dan Pranata Sos., vol. 20, no. 2, pp. 138-158, 2020.

[2] M. T. Kamil, "Prototype Kendali Pintu Otomatis Menggunakan e-KTP, Fingerprint Berbasis Arduino Dan Web." STMIK Widya Cipta Dharma, 2020.

[3] N. S. Subawa and N. W. Widhiasthini, Waralaba 4.0: Isu, Tren dan Evolusi Waralaba di Era Digital, vol. 2. Nilacakra, 2020.

[4] R. Yuniarti, I. P. Tama, A. Eunike, and Y. Sumantri, Green Supply Chain Management dan Studi Kasus di Dunia Industri. Universitas Brawijaya Press, 2018.

[5] S. T. Hati, "Isu-isu sosial kontemporel," 2019.

[6] B. Seok, J. Park, and J. H. Park, "A lightweight hash-based blockchain architecture for industrial loT," Appl. Sci., vol. 9, no. 18, p. 3740, 2019.

[7] X. Liang, J. Zhao, S. Shetty, and D. Li, "Towards data assurance and resilience in loT using blockchain," in MILCOM 2017-2017 IEEE Military Communications Conference (MILCOM), 2017, pp. 261-266.

[8] A. Winarno, "Desain E-Transkrip dengan Teknologi Blockchain," in Prosiding Seminar Nasional Pakar, 2019, pp. 1-37.

[9] S. D. K. Hu, H. N. Palit, and A. Handojo, "Implementasi Blockchain: Studi Kasus e-Voting," J. Infra, vol. 7, no. 1, pp. 183-189, 2019.

[10] T. E. H. Setia and A. Susanto, "Smart Contract Blockchain pada E-Voting," J. Inform. Upgris, vol. 5, no. 2, 2019.

[11] M. P. Febriharini, "Pelaksanaan Program e KTP Dalam Rangka Tertib Administrasi Kependudukan," Serat Acitya, vol. 5, no. 2, p. 17, 2017. 
[12] A. R. N. Ismail, K. Noviartati, S. Syahril, and A. R. Fikri, "Investasi Digital Sebagai Solusi Mengurangi Perilaku Konsumtif Milenial Masa Pandemi Covid-19," Cap. J. Ekon. dan Manaj., vol. 4, no. 2, pp. 125-136, 2021.

[13] A. M. Aziz, A. Budiyono, and A. Widjajarto, "Analisis Dan Implementasi Komunikasi Antar Node Ipfs (interplanetary File System) Pada Smart Contract Ethereum," eProceedings Eng., vol. 6, no. 2, 2019.

[14] M. D. K. Perdani, W. Widyawan, and P. I. Santosa, "Blockchain untuk Keamanan Transaksi Elektronik Perusahaan Financial Technology (Studi Kasus pada PT XYZ)," Semnasteknomedia Online, vol. 6, no. 1, pp. 1-14, 2018.

[15] D. Y. Rizaldi and I. F. Kurniawan, "Implementasi Multichain sebagai Alternatif Solusi Keamanan dan Privasi Data pada Komunikasi Perangkat Pintar Rumah," J. Informatics Comput. Sci., vol. 1, no. 02, 2019.

[16] M. Griffiths, A. Heinze, A. Fenton, and G. Fletcher, "Digital business evolution: lessons from a decade of KTP industry projects," 2018.

[17] Y. Afifah, A. Sujono, and C. H. B. Apribowo, "The line segmentation algorithm of Indonesian electronic identity card (e-KTP) for data digitization," in AIP Conference Proceedings, 2020, vol. 2217, no. 1, p. 30138.

[18] H. F. Putra, W. Wirawan, and O. Penangsang, "Penerapan Blockchain dan Kriptografi untuk Keamanan Data pada Jaringan Smart Grid," J. Tek. ITS, vol. 8, no. 1, pp. A11-A16, 2019.

[19] M. Yeni and D. Kumala, "Teknologi Blockchain untuk Transparansi dan Keamanan pada Era Digital," 2020.

[20] M. Yusup, D. Cahvadi, E. Febriyanto, and F. Budiarty, "The Impact of Socio-Economic in Digital Signature Using Blockchain Application," in 2020 8th International Conference on Cyber and IT Service Management (CITSM), 2020, pp. 1-6.

[21] T. Nurhaeni, I. Handayani, F. Budiarty, D. Apriani, and P. A. Sunarya, "Adoption of Upcoming Blockchain Revolution in Higher Education: Its Potential in Validating Certificates," in 2020 Fifth International Conference on Informatics and Computing (ICIC), 2020 , pp. $1-5$.

[22] R. Supriati, D. Aryani, and S. Maesaroh, "Asset Management Using a Web-Based Accounting Online System To Maintain Value of Company Assets," Aptisi Trans. Manag., vol. 1, no. 1, pp. 31-37, 2017.

[23] A. C. Purnomo, B. Pramono, and F. P. Oganda, "Design of Information System in Admission of New Students Based on Web in SMK Al Amanah," Aptisi Trans. Manag., vol. 3, no. 2, pp. 159-167, 2019.

[24] M. Kamil, J. Rianto, and D. Suprayogi, "Management of Deciding Decision Making Final Project Advisor in Optimizing Learning," Aptisi Trans. Manag., vol. 2, no. 2, pp. 168-176, 2019. 